\title{
Hydrogeochemical analysis of part of the alluvial aquifer, Rupendehi District, Nepal
}

\author{
*Anusha Sharma Pandey and Kristine Walraevens \\ Ghent University, Belgium \\ *Corresponding author: anusharma7586@gmail.com
}

\begin{abstract}
This study is mainly focused on detail hydrogeochemical study and water quality test of inorganic constitutes for drinking and irrigation purposes. The study area occupies part of the Siwalik and the Terai with total area of $331 \mathrm{sq}$. km. Total 30 samples were analysed at applied geology and hydrogeology laboratory, Ghent University, Belgium. The major cations $\left(\mathrm{Na}^{+}, \mathrm{Ca}^{2+}, \mathrm{Mg}^{2+}, \mathrm{K}^{+}, \mathrm{Fe}^{2+}, \mathrm{Mn}^{2+}, \mathrm{Al}^{3+}\right.$ and $\left.\mathrm{NH}_{4}{ }^{+}\right)$, anions $\left(\mathrm{Cl}^{-}, \mathrm{SO}_{4}{ }^{2-}, \mathrm{NO}_{3}{ }^{-}, \mathrm{NO}_{2}{ }^{-}, \mathrm{HCO}_{3}{ }^{-}, \mathrm{CO}_{3}{ }^{2-}, \mathrm{PO}_{4}{ }^{3-}\right.$, and $\left.\mathrm{OH}-\right)$ and trace elements $\left(\mathrm{F}^{-}\right.$and $\left.\mathrm{Br}^{-}\right)$were measured. Results were treated using Piper diagram, Scatter diagram and Stuyfzand (1986) classification of groundwater. It showed that groundwater of the study area was slightly acidic to basic in nature. $\mathrm{Ca}^{2+}$ and $\mathrm{Mg}^{2+}$ and $\mathrm{HCO}_{3}{ }^{-}$were major cations and anion for all samples. The sources of these ions in the water were from dissolution of calcite $\left(\mathrm{CaCO}_{3}\right)$ and dolomite $\mathrm{CaMg}\left(\mathrm{CO}_{3}\right)_{2}$. The amount of Na+ and $\mathrm{K}+$ was from hydrolysis reaction of silicate minerals such as K-feldspar and Na-feldspar. Small concentration of SO4-2 was from oxidation of pyrite. Most of the samples (27 out of 30) were fresh, moderately hard, $\mathrm{CaHCO}_{3}$ water type with surplus of $\left(\mathrm{Na}^{+}+\mathrm{K}^{+}+\mathrm{Mg}^{2+}\right)$. Water of the study area was found suitable both for drinking and irrigation purposes in accordance with WHO (2004) and National Drinking Water Quality Standards (2005).
\end{abstract}

Keywords: Groundwater, Aquifer, Hydrochemical Analysis, Water Quality

Paper Received: 31 Dec 2018

Paper Accepted: 31 Mar 2019

\section{INTRODUCTION}

Agriculture is a principle economic source of the country employing $65 \%$ of the population but only about $21 \%$ land is cultivatable (Prasai, 2010). Terai, the southern lowland plain, is highly productive land for cultivation because of the flat topography and fertile soil where most part of the study area situates. The main source and easily available source of water for all purposes is groundwater. Three governmental authorities are performing groundwater exploration and exploitation in the area. Two government authorities, the Groundwater Irrigation Development Division and Bhairahawa Lumbini Groundwater Irrigation Project are distributing groundwater as an irrigation water whereas, Water Supply and Sanitation Division Office is supplying deep tube well water as drinking water through pipeline system.

Water quality is a fundamental requirement for the living organism to survive. Rapid population growth change in life style, industrialization, urbanizations can be the key factors in reducing water quality in the study area. The chemical alteration of infiltrated water depends on soil- water interaction, anthropogenic activities and dissolution of mineral (Plummer et al., 2003). Quality of the groundwater is normally influenced by geology and anthropogenic activities through which it passes. Nearly $95 \%$ solute in water are calcium $\left(\mathrm{Ca}^{2+}\right)$, magnesium $\left(\mathrm{Mg}^{2+}\right)$, sodium $\left(\mathrm{Na}^{+}\right)$, potassium $\left(\mathrm{K}^{+}\right)$, chloride $\left(\mathrm{Cl}^{-}\right)$, sulphate $\left(\mathrm{SO}_{4}^{2-}\right)$ and bicarbonate $\left(\mathrm{HCO}_{3}^{-}\right)$(Plummer et al., 2003). It further depends on certain factors such as precipitation, temperature and $\mathrm{pH}$. Aquifers have been developed within the unconsolidated fluvial sediment systems provide large quantities of water. However, these aquifers are commonly unconfined, occur at shallow depth and are vulnerable to contamination by surface activities. Direct disposal of wastewater and solid from industry and household to the surface water degrades not only surface water but also groundwater in urban area of the country. Use of pesticides and chemical fertilizer also degrades the quality of groundwater in shallow depth. In this scenario, detail hydrogeochemical study is the principal objective of this research.

\section{Study area}

The study lies in the Rupendehi District, south-western part of the Nepal. It is bounded by latitude $27^{\circ} 30^{\prime}$ to $27^{\circ} 45^{\prime} \mathrm{N}$ and longitude $83^{\circ} 18^{\prime}$ to $83^{\circ} 30^{\prime} \mathrm{E}$. Most part of the area is relatively flat, and the elevation gradually increases towards the north. Location map is shown Fig. 1. It has sub-tropical climate characterized by hot summers and relatively cool and dry winters. Surface drainage is from north to south by means of rivers and streams. The Tinau River and the Dano Rivers are the main rivers. Texture of the soil of the area is mainly moderately fine to fine such as silty loam, silty clay, loam and silty clay (BLGWIP, 2000).

\section{GEOLOGICAL AND HYDROGEOLOGICAL SETTING}

Study area belongs to the Terai and the Siwalik zones of Nepal. The Terai is the southernmost part of Nepal with flat 


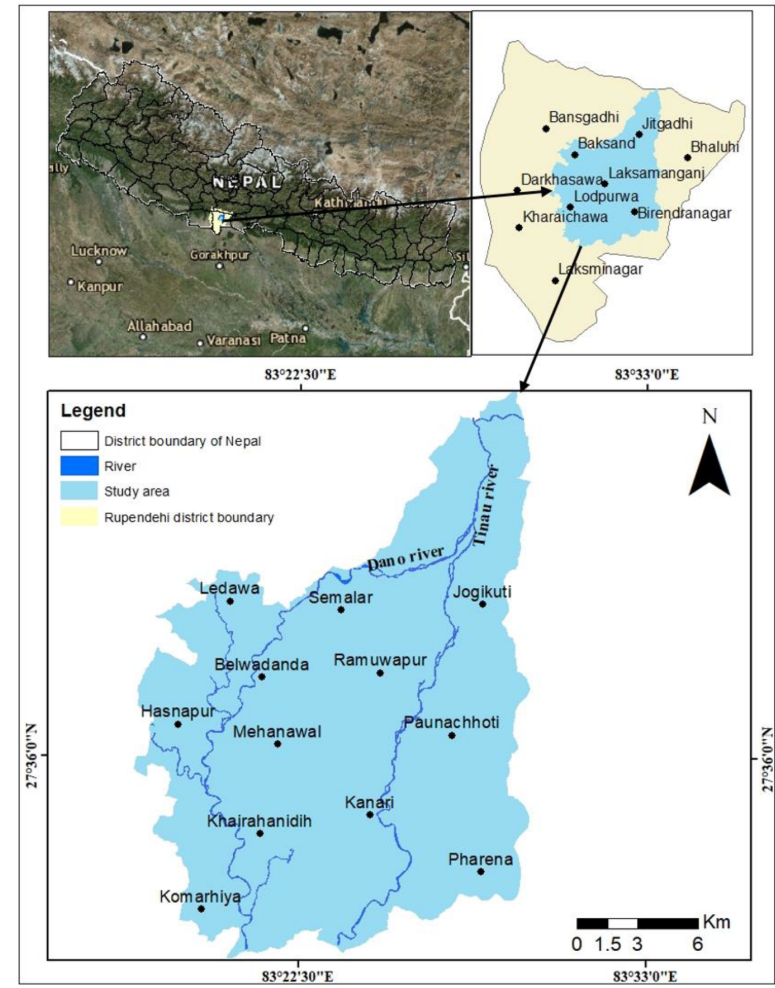

Fig.1: Location map of the study area topography which extends from Nepal-India border (south) to the Siwalik (north). Both zones are separated by a thrust known as the Main Frontal Thrust (MFT)(Fig. 2a). The Terai Zone consists of alluvial deposits of Pleistocene age which is weathering product of rocks of the Siwalik and the Lesser Himalaya zones. The Siwalik Zone consists of sedimentary rock such as shale, mudstone, sandstone and conglomerate ranging in age from Middle Miocene to Pleistocene.

Intercalation of coarse sediments is found throughout the study area as shown in geological cross-sections (Figs. 2b and 2c). Thickness of sediments varies both in vertical and lateral directions. The proportion of the coarser sediments decreases from the north to the south (Fig. 2b) and moving away from the main rivers (Fig. 2c). Considering coarser sediments (sand, gravel and pebble) as an aquifer material, northern part of the study area has thick unconfined aquifer whereas, southern part has only semi-confined aquifer bounded by thick aquitard. Similarly, thickness of the aquifer decreases moving from the east to the west.

\section{METHODOLOGY}

\section{Groundwater sampling and lab work}

Total 30 samples were collected including springs, Deep Tube Wells (DTWs), Shallow Tube Wells (STWs) and river. Location of individual samples is shown in the Fig. 3. Twelve
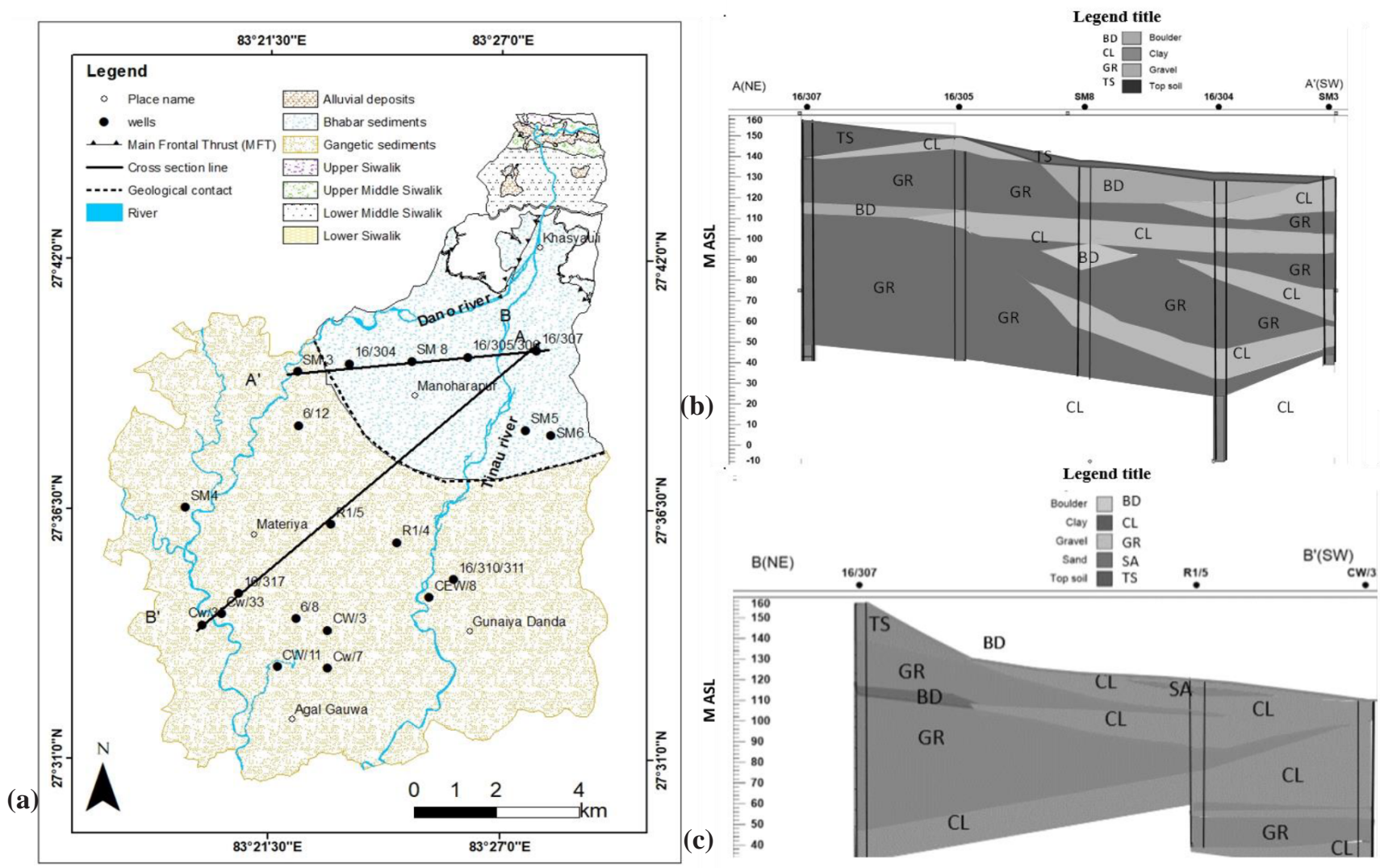

Fig. 2: Geological map of the study area with cross-section lines and geological cross-section passing along the line A-A' and B-B' 
out of sixteen DTWs were being used for only irrigation and remaining four DTWs were being used both for irrigation and drinking purposes. Polyethylene half-liter drinking water bottles were used as sample bottles. These were ringed three times and were fully filled. All the samples were brought to Applied Geology and Hydrogeology laboratory, Ghent University, Belgium, where major cations $\left(\mathrm{Na}^{+}, \mathrm{Ca}^{2+}, \mathrm{Mg}^{2+}, \mathrm{K}^{+}, \mathrm{Fe}^{2+}, \mathrm{Mn}^{2+}\right.$, $\mathrm{Al}^{3+}$ and $\left.\mathrm{NH}^{4+}\right)$, anions $\left(\mathrm{Cl}^{-}, \mathrm{SO}_{4}{ }^{2-}, \mathrm{NO}_{3}{ }^{-}, \mathrm{NO}_{2}{ }^{-}, \mathrm{HCO}_{3}{ }^{-}, \mathrm{CO}_{3}{ }^{2-}\right.$, $\mathrm{PO}_{4}{ }^{3-}$, and $\left.\mathrm{OH}^{-}\right)$and trace elements $(\mathrm{F}-$ and $\mathrm{Br}-$ ) were measured. $\mathrm{Na}^{+}, \mathrm{Ca}^{2+}, \mathrm{Mg}^{2+}, \mathrm{Fe}^{2+}$ and $\mathrm{Mn}^{2+}$ were measured using Atomic Absorption Spectrometry (AAS). $\mathrm{Cl}^{-}, \mathrm{NO}^{3-}, \mathrm{NO}^{2-}, \mathrm{PO}_{4}{ }^{2-}$ and $\mathrm{NH}_{4}{ }^{+}$were measured by spectrophotometry. $\mathrm{HCO}_{3}{ }^{-}$and $\mathrm{SO}_{4}{ }^{2-}$ were measured after titration with $\mathrm{HCL}^{-} \mathrm{F}^{-}$and $\mathrm{Br}^{-}$was measured with specific ion electrodes. In addition of chemical properties of water, $\mathrm{pH}$ and $\mathrm{EC}$ were also measured using $\mathrm{pH}$ electrode and EC electrode, respectively.

\section{Hydrogeochemical interpretation method}

For the analysis of the obtained lab result Piper diagram, scatter diagram and a classification (Stuyfzand, 1986) were applied. Piper diagram was plotted using the software Aquachem 3.70. The percentage of major cations and anions from each sample in (meq/l) was plotted in a separate triangular diagram. Then each point was transferred to the diamond shape diagram. The position of the point in this diagram gave the type of water. Each corner of this diagram showed different water type namely, calcium bicarbonate $\left(\mathrm{Ca}-\mathrm{HCO}_{3}\right)$, sodium bicarbonate $(\mathrm{Na}-$ $\left.\mathrm{HCO}_{3}\right)$, sodium chloride $(\mathrm{Na}-\mathrm{Cl})$ and calcium chloride $(\mathrm{Ca}-\mathrm{Cl})$. The same software Aquachem 3.70 was used plotting scatter diagram where two parameters were plotted in the $\mathrm{X}-\mathrm{Y}$ axis to see relation between different ions. Stuyfzand (1986) classification combines four symbols. First symbol was based on the Cl- content (mg/l) in sample, which was subdivided into Fresh, Fresh brackish, Brackish, Brackish salt, Salt and Hyperhaline. The second symbol was based on the total hardness. It expressed the concentration of $\mathrm{Ca}^{2+}$ and $\mathrm{Mg}^{2+}$ in water. Third symbol was based on the water type, the dominant cations and anions. Two different triangles, each for cation and anion were used to plot sum of major cation and anion with their hydrochemical families. These families were represented at the corner of their respective triangles and consisted of hydrochemical pair constituents. Each pair again consisted of one or more individual constituent and was separated by brackets. The fourth symbol of the classification was cation exchange code, which was based on nature of the cation exchange. The sum of the $\mathrm{Na}^{+}, \mathrm{K}^{+}$and $\mathrm{Mg}^{2+}$ was corrected for the seawater contribution, determined from the $\mathrm{Cl}^{-}$content. The hardness and cation exchange code in the classification was very useful studying salt water intrusion phenomenon.

Total dissolved solid (TDS) was obtained by summing up all analysed cations and anions present in the water sample. Ionic balance was checked by using the following formula where sum of the anions (meq/l) must be equal to sum of cations (meq/l) because of electro-neutrality.

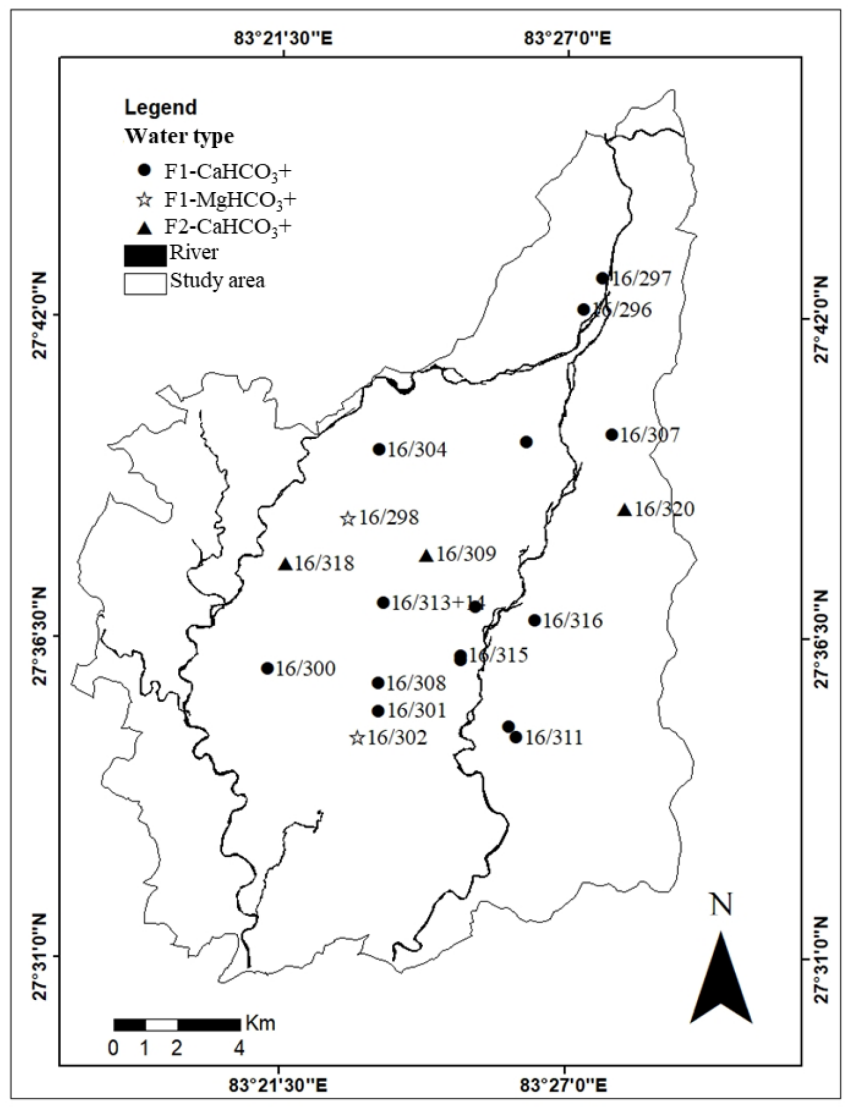

Fig. 3: Sampling location point

Ionic balance $=[($ SUMc - SUMa $) /($ SUMc + SUMa $)] .100$

where, SUMc is the sum of cations and SUMa is the sum of anions. The margin of the error is accepted $\pm 5 \%$

\section{Water quality test method}

Deep tube wells in the study area were installed by government of Nepal. Groundwater is being distributed through pipeline system mainly in city area both for irrigation and for drinking purposes. In the case of unavailability of deep tube wells, shallow tube wells were being used for all purposes. The suitability of groundwater especially for drinking purposes was tested by comparing the lab analytical result with standards of WHO (WHO, 2004) and standards of government of Nepal (DWSS, 2005).

Similarly, the quality of water for irrigation was determined using several classification schemes. A classification of United States Department of Agriculture (USDA, 1954) was applied for Sodium Adsorption ratio (SAR) and Electrical Conductivity (EC) concentration in water. Quality of irrigation water was also tested based in $\mathrm{Cl}^{-}$and $\mathrm{SO}_{4}{ }^{2-}$ content, $\mathrm{Na}^{+}$ percentage (Hopkins, et al., 2007; Mtoni et al., 2013) and Magnesium Hazard (MH). SAR, $\mathrm{Na}+\%$ and $\mathrm{MH}$ was calculated using the following formulas. 


$$
\begin{aligned}
& \mathrm{SAR}=\mathrm{Na}^{+} /\left(\left(\mathrm{Ca}^{2+}+\mathrm{Mg}^{2+}\right) / 2\right) 0.5 \\
& \mathrm{Na}^{+} \%=\left(\mathrm{Na}^{+} /\left(\mathrm{Na}^{+}+\mathrm{Ca}^{2+}+\mathrm{Mg}^{2+}+\mathrm{K}^{+}\right)\right) * 100 \\
& \mathrm{MH}=\left(\mathrm{Mg}^{2+} /\left(\mathrm{Ca}^{2+}+\mathrm{Mg}^{2+}\right)\right) * 100
\end{aligned}
$$

\section{RESULTS AND DISCUSSIONS}

The laboratory results of the 30 samples are listed (Table 1). The $\mathrm{pH}$ of the water ranges from 6.71 to 7.79. Dominant cations and anion are $\mathrm{Ca}^{2+}, \mathrm{Mg}^{2+}$ and $\mathrm{HCO}_{3}{ }^{-}$for all samples as shown in the Piper diagram (Fig. 4). Eighteen samples have the $\mathrm{Ca}-\mathrm{Mg}-\mathrm{HCO}_{3}$ water type whereas remaining 12 samples are $\mathrm{Mg}-\mathrm{Ca}-\mathrm{HCO}_{3}$.

All samples contain less than $150 \mathrm{mg} / \mathrm{l} \mathrm{Cl}$ - ion, based on the first symbol of Stuyfzand (1986) classification, water samples are classified as fresh water, and code $\mathrm{F}$ is given for the representation. Total hardness for 26 samples is less than $20{ }^{\circ} \mathrm{F}$ and more than $20\left({ }^{\circ} \mathrm{F}\right)$ for four samples (16-307, 16-312, 16-318 and 16-320). Based on the third symbol of the classification, 28 samples have $\mathrm{Ca}^{2+}$ and $\mathrm{HCO}_{3}{ }^{-}$as a dominant cation and anion, respectively, whereas $\mathrm{Mg}^{2+}$ is higher than the calcium in two samples (16-298 and 16-302). Based on the fourth symbol of classification all samples have surplus of $\left(\mathrm{Na}^{+}+\mathrm{K}^{+}+\mathrm{Mg}^{2+}\right)$.

A mapping of the water type based on the Stuyfzand (1986) classification is shown in Fig. 5. The calculated value of saturation index for calcite and dolomite ranges from -2.08 to 0.33. As listed in Table 2, most of the samples are undersaturated with respect to calcite and dolomite. Three spring

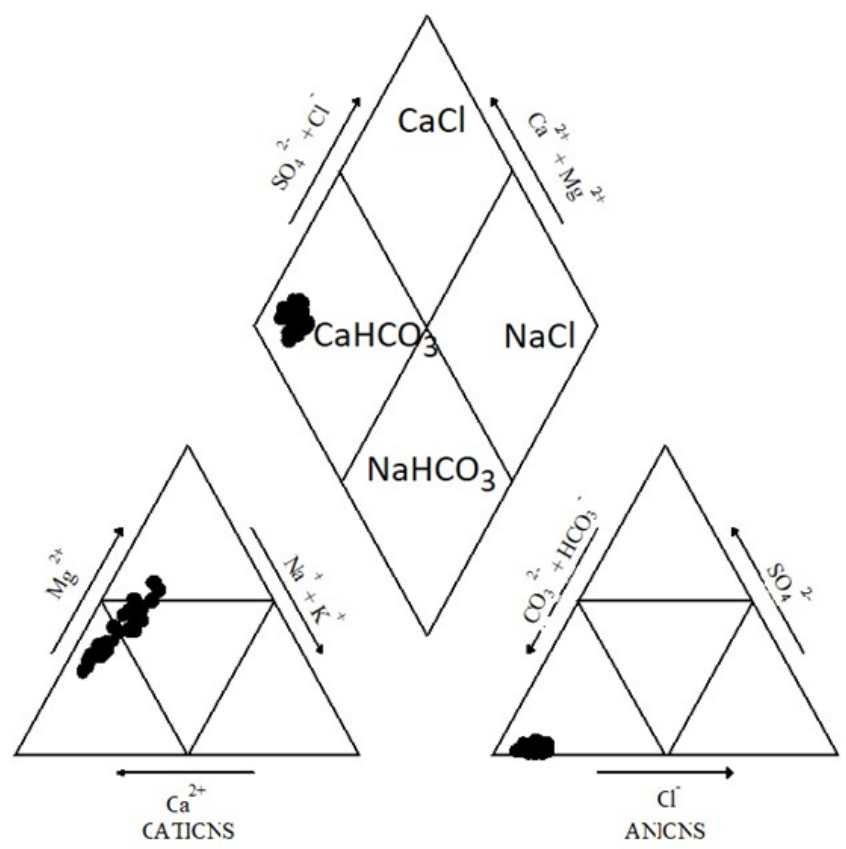

Fig. 4: Piper diagram plot of the area to know water type, unit of the ions plotted in this diagram is $\mathrm{mg} / \mathrm{l}$ samples from Shanti toll (16/294), Siddharth highway (16/295) and Tamnagar (16/296) are saturated with respect to both calcite and dolomite. A deep tube well sample (Shankhanagar, 16/307) is saturated with respect to calcite but under saturate with dolomite.

Cross plots in the Fig. 6 shows the relationship of different ions such as $\mathrm{Ca}^{2+}, \mathrm{Mg}^{2+}, \mathrm{SO}_{4}{ }^{2-}$, with and TDS. There is linear relation between ions $\mathrm{Ca}^{2+}$ and $\mathrm{HCO}_{3}{ }^{-}$with TDS co-relation coefficient 0.53 and 0.94 , respectively. High co-relation coefficient value indicates high concentration of calcium and bicarbonate ion with respect to total dissolve solid in water samples. There is also small concentration of magnesium. It indicates chemistry of the water of the area is from carbonate mineral dissolution such as dissolution of calcite $\left(\mathrm{CaCO}_{3}\right)$, dolomite $\mathrm{CaMg}\left(\mathrm{CO}_{3}\right)_{2}$.

Release of major ions in the water samples is from following reactions. When rainwater meets atmospheric $\mathrm{CO}_{2}$, it becomes slightly acidic

$$
\begin{aligned}
& \mathrm{H}_{2} \mathrm{O}+\mathrm{CO}_{2}=\mathrm{H}_{2} \mathrm{CO}_{3} \\
& \mathrm{H}_{2} \mathrm{CO}_{3}=\mathrm{HCO}_{3}{ }^{-}+\mathrm{H}+
\end{aligned}
$$

When this slightly acidic water infiltrates through the groundwater it dissolves carbonate minerals if they are present

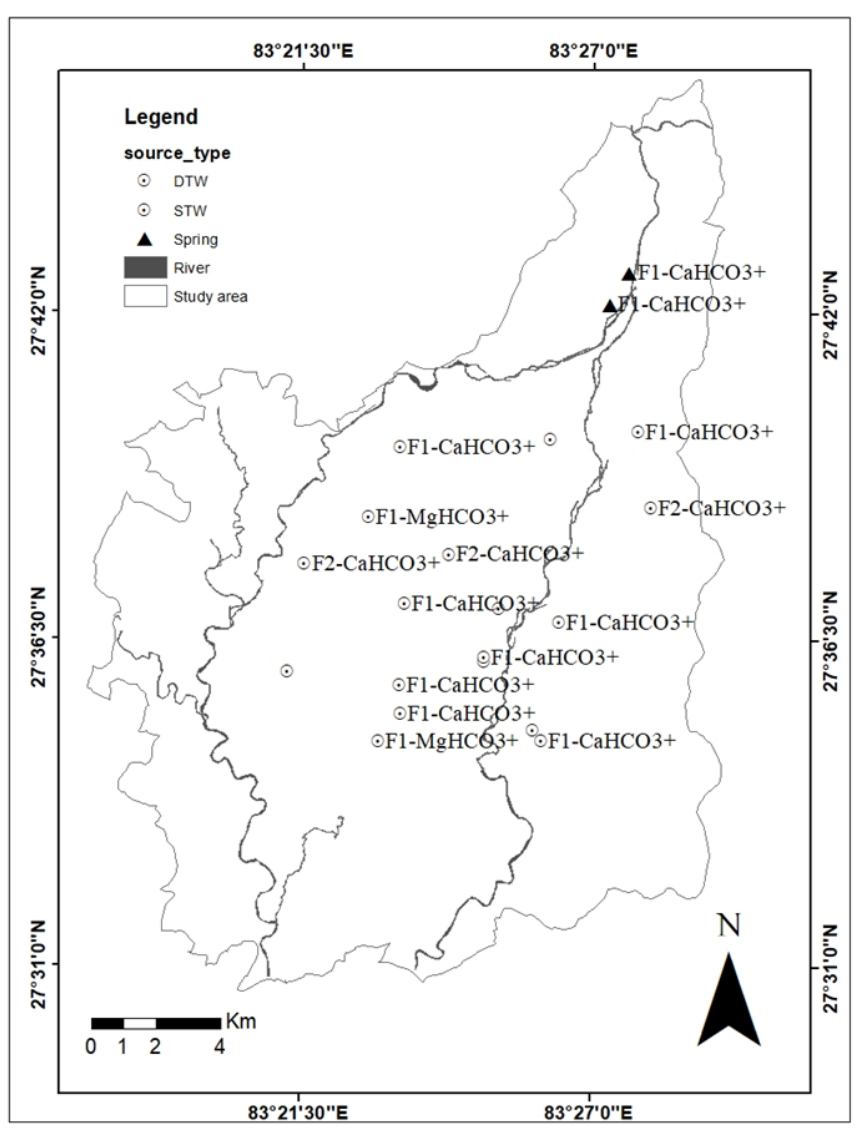

Fig. 5: Mapping of the water type based on Stuyfzand (1986) classification 


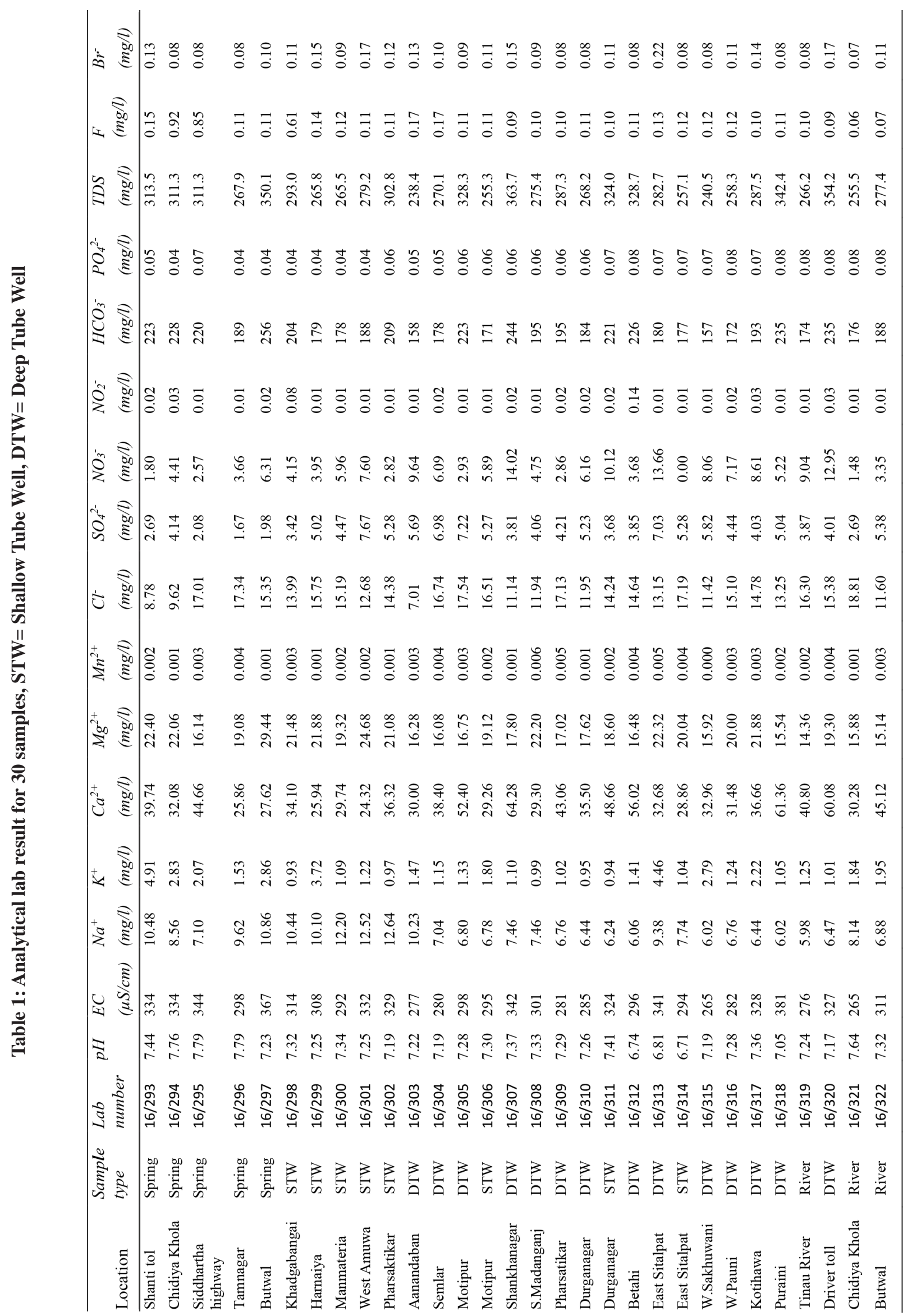


Table 2: Saturation index calculation for calcite and dolomite

\begin{tabular}{|c|c|c|c|c|c|}
\hline Samples & Type & Calcite & $\begin{array}{l}\text { Result with } \\
\text { respect to calcite }\end{array}$ & Dolomite & $\begin{array}{l}\text { Result with respect } \\
\text { to dolomite }\end{array}$ \\
\hline $16 / 293$ & Spring & -0.08 & undersaturation & -0.06 & undersaturation \\
\hline $16 / 294$ & Spring & 0.17 & supersaturation & 0.53 & supersaturation \\
\hline $16 / 295$ & Spring & 0.33 & supersaturation & 0.57 & supersaturation \\
\hline $16 / 296$ & Spring & 0.04 & supersaturation & 0.31 & supersaturating \\
\hline $16 / 297$ & Spring & -0.41 & undersaturation & -0.44 & undersaturation \\
\hline $16 / 298$ & STW & -0.3 & undersaturation & -0.46 & undersaturation \\
\hline $16 / 299$ & STW & -0.55 & undersaturation & -0.82 & undersaturation \\
\hline $16 / 300$ & STW & -0.4 & undersaturation & -0.63 & undersaturation \\
\hline $16 / 301$ & STW & -0.56 & undersaturation & -0.77 & undersaturation \\
\hline $16 / 302$ & STW & -0.41 & undersaturation & -0.71 & undersaturation \\
\hline $16 / 303$ & DTW & -0.57 & undersaturation & -1.05 & undersaturation \\
\hline $16 / 304$ & DTW & -0.45 & undersaturation & -0.93 & undersaturation \\
\hline $16 / 305$ & DTW & -0.13 & undersaturation & -0.41 & undersaturation \\
\hline $16 / 306$ & STW & -0.46 & undersaturation & -0.76 & undersaturation \\
\hline $16 / 307$ & DTW & 0.08 & supersaturation & -0.05 & undersaturation \\
\hline $16 / 308$ & DTW & -0.38 & undersaturation & -0.52 & undersaturation \\
\hline $16 / 309$ & DTW & -0.26 & undersaturation & -0.56 & undersaturation \\
\hline $16 / 310$ & DTW & -0.39 & undersaturation & -0.74 & undersaturation \\
\hline $16 / 311$ & STW & -0.03 & undersaturation & -0.13 & undersaturation \\
\hline $16 / 312$ & DTW & -0.72 & undersaturation & -1.63 & undersaturation \\
\hline $16 / 313$ & DTW & -0.96 & undersaturation & -1.74 & undersaturation \\
\hline $16 / 314$ & STW & -1.14 & undersaturation & -2.08 & undersaturation \\
\hline $16 / 315$ & DTW & -0.56 & undersaturation & -1.09 & undersaturation \\
\hline $16 / 316$ & DTW & -0.45 & undersaturation & -0.75 & undersaturation \\
\hline $16 / 317$ & DTW & -0.26 & undersaturation & -0.39 & undersaturation \\
\hline $16 / 318$ & DTW & -0.42 & undersaturation & -1.09 & undersaturation \\
\hline $16 / 319$ & River & -0.38 & undersaturation & -0.86 & undersaturation \\
\hline $16 / 320$ & DTW & -0.18 & undersaturation & -0.51 & undersaturation \\
\hline $16 / 321$ & River & -0.07 & undersaturation & -0.07 & undersaturation \\
\hline $16 / 322$ & River & -0.22 & undersaturation & -0.56 & undersaturation \\
\hline
\end{tabular}

on the way of water. The reactions taking place during the dissolution of calcite and dolomite are

$$
\begin{aligned}
& \mathrm{CaCO}_{3}+\mathrm{H}^{+}=\mathrm{Ca}^{2+}+\mathrm{HCO}_{3}^{-} \\
& \mathrm{CaMg}\left(\mathrm{CO}_{3}\right)_{3}+2 \mathrm{H}^{+}=\mathrm{Ca}^{2+}+\mathrm{Mg}^{2+}+2 \mathrm{HCO}_{3}^{-}
\end{aligned}
$$

Small concentration of $\mathrm{Na}^{+}, \mathrm{K}^{+}$and $\mathrm{SO}_{4}{ }^{2-}$ in water can be released in water from hydrolysis reaction of silicate minerals and pyrite oxidation as following reaction.

$$
\begin{aligned}
& \left(\mathrm{K}^{+}, \mathrm{Na}^{+}\right) \mathrm{AlSi}_{3} \mathrm{O}_{8}+\mathrm{H}^{+}+\mathrm{H}_{2} \mathrm{O}= \\
& \quad \text { clay mineral }+\left(\mathrm{K}^{+}, \mathrm{Na}^{+}\right)+\mathrm{SiO}_{2}(\mathrm{aq}) \\
& 2 \mathrm{FeS}_{2}+2 \mathrm{H}_{2} \mathrm{O}+7 \mathrm{O}_{2}=2 \mathrm{Fe}^{2+}+4 \mathrm{SO}_{4}{ }^{2-}
\end{aligned}
$$

Analytical lab results are compared with the guidelines of WHO (2004) and with the National Drinking Water Quality Standards (DWSS, 2005) (Table 3). The concentration of inorganic constituents in every samples are below guidelines values which indicates water of the study area is good for drinking purposes. Calculated SAR value of the area ranges from 0.97-2.53. Based on USDA classification of SAR, water of the area is excellent for irrigation (Table 4 and 5). As shown in Table 6, value of $\mathrm{SO}_{4}{ }^{2-}, \mathrm{Cl}^{-}$and $\mathrm{Na} \%$ is below $192(\mathrm{mg} / \mathrm{l})$, $142(\mathrm{mg} / \mathrm{l})$ and $20 \%$, respectively which indicates quality of water for irrigation is excellent. Based on Szabolcs and Darab (1964) classification value of magnesium hazard below $50 \%$ is considered suitable water for irrigation and magnesium hazard for all samples of the area ranges between $41.59-20.21 \%$ (Table 7).

\section{CONCLUSIONS}

Most part of the study area consists of heterogenous mixture of alluvial sediments ranging in size from boulder to clay. Thickness of the aquifer varies throughout the area. In the north-eastern part, both confined and unconfined aquifers occur whereas in the southern part only confined aquifer occurs. Groundwater of the area is slightly acidic to basic. Major 


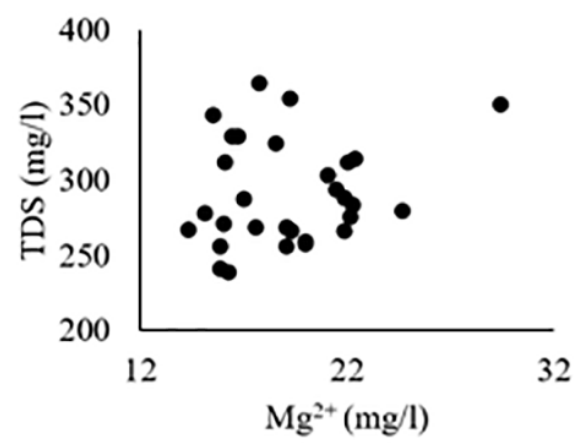

(a)

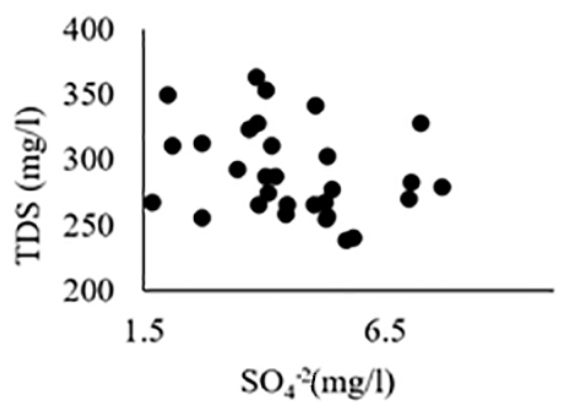

(c)

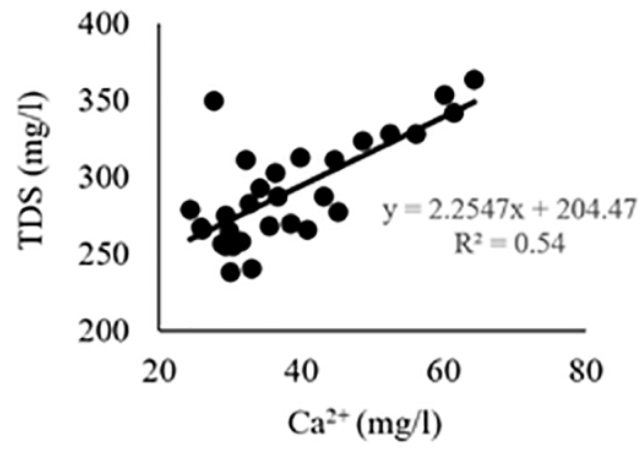

(b)

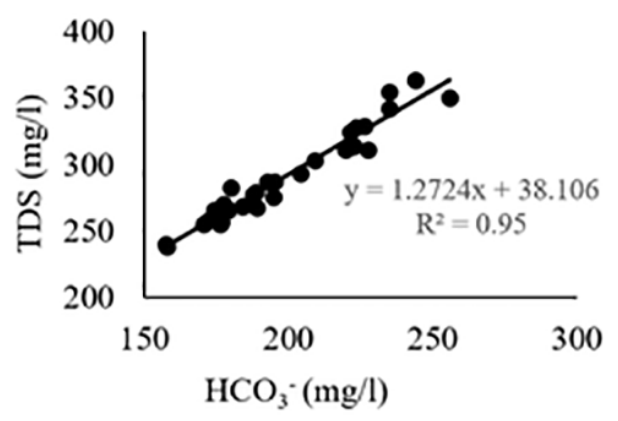

(d)

Fig. 6: Cross plots showing the relation of dominant cations with TDS

Table 3: Comparison of WHO and National drinking water quality standards with the samples

\begin{tabular}{llll}
\hline Parameters & WHO standards (2004) & $\begin{array}{l}\text { National Drinking Water Quality } \\
\text { Standards (DWSS, 2005), Government } \\
\text { of Nepal }\end{array}$ & $\begin{array}{l}\text { Ranges of parameters } \\
\text { in water samples }\end{array}$ \\
\hline $\mathrm{pH}$ & $6.5-9.2$ & $6.5-8.5$ & $6.74-7.79$ \\
$\mathrm{EC}(\mu \mathrm{S} / \mathrm{cm})$ & $500-1500$ & 1500 & $293-653$ \\
$\mathrm{TDS}(\mathrm{mg} / \mathrm{l})$ & 1000 & 1000 & $238-364$ \\
$\mathrm{Na}+(\mathrm{mg} / \mathrm{l})$ & 200 & - & $5.98-12.6$ \\
$\mathrm{~K}(\mathrm{mg} / \mathrm{l})$ & 200 & - & $0.93-4.91$ \\
$\mathrm{Ca} 2+(\mathrm{mg} / \mathrm{l})$ & 200 & 200 & $24-64$ \\
$\mathrm{SO} 42-(\mathrm{mg} / \mathrm{l})$ & 250 & 250 & $1.67-7.67$ \\
$\mathrm{Cl}-(\mathrm{mg} / \mathrm{l})$ & 250 & 250 & $7-19$ \\
$\mathrm{Fe}(\mathrm{mg} / \mathrm{l})$ & 0.3 & 0.3 & 0 \\
$\mathrm{Br}-(\mathrm{mg} / \mathrm{l})$ & 2.4 & - & $0.07-0.22$ \\
$\mathrm{~F}^{-}(\mathrm{mg} / \mathrm{l})$ & 1.5 & $0.5-1.5$ & $0.06-0.92$ \\
$\mathrm{NO}_{3}^{-}(\mathrm{mg} / \mathrm{l})$ & 50 & 50 & 14.02 \\
\hline
\end{tabular}

dissolves ions are $\mathrm{Ca}^{2+}$ and $\mathrm{Mg}^{2+}, \mathrm{HCO}_{3}{ }^{-}, \mathrm{Na}^{+}, \mathrm{K}^{+}$and $\mathrm{SO}^{2-}$. Calcium bicarbonate is dominant water type of the area. Most of samples are fresh, moderately hard calcium bicarbonate water type and are surplus in $\left(\mathrm{Na}^{+}+\mathrm{K}^{+}+\mathrm{Mg}^{2+}\right)$ which is denoted by $\mathrm{F} 1-\mathrm{CaHCO}_{3}{ }^{+}$. The sources of these ions in the water are from dissolution of calcite, dolomite, feldspar, and pyrite. Quality of water in terms of inorganic constituents is good both for irrigation and drinking purposes.

\section{REFERENCES}

BLGWIP, 2000, Final report on effectiveness of Investment: Bhairahawa -Lumbini Groundwater Irrigation Project (BLGWIP). Bhairahawa-Lumbini Groundwater Irrigation Project (BLGWIP), pp. 1-80.

DWSS, 2005, Implementation Directives for National Drinking Water Quality Standards, pp. 1-22. 
Table 4: Calculated value of different parameters for irrigation water quality test, $\mathrm{SAR}=$ Sodium Adsorption Ratio, MH= Magnesium Hazard

\begin{tabular}{|c|c|c|c|c|c|}
\hline Lab number & $\mathrm{SO}_{4}^{2-}$ & $\mathrm{Cl}^{-}$ & SAR & $\mathrm{Na} \%$ & $\mathrm{MH}$ \\
\hline $16 / 293$ & 2.7 & 8.8 & 1.88 & 13.52 & 36.05 \\
\hline $16 / 294$ & 4.1 & 9.6 & 1.65 & 13.06 & 40.75 \\
\hline $16 / 295$ & 2.1 & 17.0 & 1.29 & 10.15 & 26.55 \\
\hline $16 / 296$ & 1.7 & 17.3 & 2.03 & 17.15 & 42.46 \\
\hline $16 / 297$ & 2.0 & 15.4 & 2.03 & 15.34 & 51.59 \\
\hline $16 / 298$ & 3.4 & 14.0 & 1.98 & 15.59 & 38.65 \\
\hline $16 / 299$ & 5.0 & 15.7 & 2.07 & 16.39 & 45.75 \\
\hline $16 / 300$ & 4.5 & 15.2 & 2.46 & 19.57 & 39.38 \\
\hline $16 / 301$ & 7.7 & 12.7 & 2.53 & 19.96 & 50.37 \\
\hline $16 / 302$ & 5.3 & 14.4 & 2.36 & 17.80 & 36.72 \\
\hline $16 / 303$ & 5.7 & 7.0 & 2.13 & 17.64 & 35.18 \\
\hline $16 / 304$ & 7.0 & 16.7 & 1.35 & 11.23 & 29.52 \\
\hline $16 / 305$ & 7.2 & 17.5 & 1.16 & 8.80 & 24.22 \\
\hline $16 / 306$ & 5.3 & 16.5 & 1.38 & 11.90 & 39.52 \\
\hline $16 / 307$ & 3.8 & 11.1 & 1.16 & 8.23 & 21.69 \\
\hline $16 / 308$ & 4.1 & 11.9 & 1.47 & 12.44 & 43.11 \\
\hline $16 / 309$ & 4.2 & 17.1 & 1.23 & 9.96 & 28.33 \\
\hline $16 / 310$ & 5.2 & 11.9 & 1.25 & 10.64 & 33.17 \\
\hline $16 / 311$ & 3.7 & 14.2 & 1.08 & 8.38 & 27.65 \\
\hline $16 / 312$ & 3.9 & 14.6 & 1.01 & 7.58 & 22.73 \\
\hline $16 / 313$ & 7.0 & 13.2 & 1.79 & 13.63 & 40.58 \\
\hline $16 / 314$ & 5.3 & 17.2 & 1.57 & 13.42 & 40.98 \\
\hline $16 / 315$ & 5.8 & 11.4 & 1.22 & 10.43 & 32.57 \\
\hline $16 / 316$ & 4.4 & 15.1 & 1.33 & 11.36 & 38.85 \\
\hline $16 / 317$ & 4.0 & 14.8 & 1.19 & 9.58 & 37.38 \\
\hline $16 / 318$ & 5.0 & 13.3 & 0.97 & 7.17 & 20.21 \\
\hline $16 / 319$ & 3.9 & 16.3 & 1.14 & 9.58 & 26.03 \\
\hline $16 / 320$ & 4.0 & 15.4 & 1.03 & 7.45 & 24.31 \\
\hline $16 / 321$ & 2.7 & 18.8 & 1.69 & 14.50 & 34.40 \\
\hline $16 / 322$ & 5.4 & 11.6 & 1.25 & 9.96 & 25.12 \\
\hline
\end{tabular}

Table 5: Classification of irrigation water quality based on SAR value

\begin{tabular}{llll}
\hline SAR & \multicolumn{1}{c}{ Water class } & Quality of water & Samples \\
\hline$<10$ & Low sodium water (S1) & Excellent & All samples \\
$10-18$ & Medium sodium water (S2) & Good & \\
$18-26$ & High sodium water (S3) & permissible & \\
$>26$ & Very high sodium water (S4) & $\begin{array}{l}\text { Doubtful- } \\
\text { unsuitable }\end{array}$ \\
& & & \\
\hline
\end{tabular}

Table 6: Classification of irrigation water based on $\mathrm{SO}_{4}{ }^{2-}$, $\mathrm{Na}^{+}, \%$ and $\mathrm{Cl}^{-}$,

\begin{tabular}{llcll}
\hline $\mathrm{SO}_{4}{ }^{2-}(\mathrm{mg} / \mathrm{l})$ & $\mathrm{Cl}^{-}(\mathrm{mg} / \mathrm{l})$ & $\left(\mathrm{Na}^{+} \%\right)$ & Quality of water & Samples \\
\hline$<192$ & $<142$ & $<20$ & Excellent & All samples \\
$192-336$ & $142-249$ & $20-40$ & Good & \\
$336-575$ & $249-426$ & $40-60$ & Permissible & \\
$575-960$ & $426-710$ & $60-80$ & Doubtful & \\
$>950$ & $>710$ & $>80$ & Unsuitable & \\
\hline
\end{tabular}

Table 7: Quality classification of irrigation water based on Magnesium Hazard (MH)(Szabolcs and Darab, 1964)

\begin{tabular}{lll}
\hline Magnesium Hazard (\%) & Quality of water & Samples category \\
\hline$<50$ & Suitable & All samples \\
$>50$ & Harmful & \\
\hline
\end{tabular}

Hopkins, B. G., Horneck, D. A., Stevens, R. G., Ellsworth, J. W., and Sullivan, D. M., 2007, Managing Irrigation Water Quality for crop production in the Pacific Northwest. A Pacific Northwest Extension Publication, pp. 1-21.

Mtoni, Y., Mjemah, I.C., Bakundukize, C., Van Camp, M., Martens, K., and Walraevens, K., 2013, Saltwater intrusion and nitrate pollution in the coastal aquifer of Dar es Salaam, Tanzania. Environmental Earth Sciences, v. 70, pp. 1091-1111. https://doi.org/10.1007/s12665-012-21977

Plummer, L.N., Bexfield, L.M., and Anderholm, S.K., 2003, How ground-water chemistry helps us understand the aquifer. Geological Survey Circular, pp. 92-93.

Prasai, B.K., 2010, National issue paper on the agriculture sector (adaptation), pp.1-24

Stuyfzand, P.J., 1986, A new hydrochemical classification of water types with examples of application to the Netherlands. H2O, v.19, pp. 562-568.

Szabolcs, I. and Darab, C., 1964, The Influence of Irrigation Water of High Sodium Carbonate Content of Soils. Proceedings of 8th International Congress of ISSS, Trans II, pp. 803-812.

USDA., 1954, Handbook No. 60?: United States Department of Agriculture (USDA). Washington, DC, US Government Printing Office, pp. 1-160.

WHO, 2004, Guidelines for Drinking-water Quality, Geneva, $1-27$. 